\title{
Animal health, welfare and production problems in organic weaner pigs
}

\author{
Christine Leeb • Lene Hegelund • Sandra Edwards • \\ Helena Mejer • Allan Roepstorff • Tine Rousing • \\ Albert Sundrum • Marianne Bonde
}

Received: 8 May 2013 / Accepted: 17 October 2013 / Published online: 17 November 2013

(C) Springer Science+Business Media Dordrecht 2013

\begin{abstract}
This paper reviews the available information on the different health and animal welfare issues in organic pigs in relation to weaning. It addresses the most relevant health and welfare problems and reviews their potential hazards and associated risk factors. Regarding health, problems related to post weaning diarrhoea, cold stress, skin lesions, endoparasites and post weaning multisystemic wasting syndrome are described. Reasons for distress and frustration in weaned piglets are identified as mainly separation from the mother, a new environment, mixing and fear of humans. Finally, hazards and risk factors for health and welfare in organic weaners are related to animal characteristics, housing systems, feed/nutrition and management. Generally, it is concluded that diseases around weaning are multifactorial in nature, with several factors contributing simultaneously as stressors at the time of weaning. In order to solve problems around weaning, the complexity and the
\end{abstract}

C. Leeb $(\bowtie)$

Division of Livestock Sciences, Department of Sustainable Agricultural Systems, University of Natural Resources and Life Sciences, Vienna (BOKU),

Gregor-Mendel-Strasse 33, 1180 Vienna, Austria

e-mail: christine.leeb@boku.ac.at

S. Edwards

School of Agriculture, Food and Rural Development, Agriculture Building, University of Newcastle upon Tyne, Newcastle upon Tyne NE1 7RU, UK

H. Mejer · A. Roepstorff

Danish Centre for Experimental Parasitology,

Faculty of Life Sciences, University of Copenhagen,

Dyrlaegevej 100, 1870 Frederiksberg C, Denmark individuality of farm systems need to be taken into account.

Keywords Health · Organic · Weaned piglet · Welfare

\section{Introduction}

In semi-natural conditions, weaning of piglets is a gradual process involving a reduction in suckling frequency, with a concomitant increase in foraging activity and the ingestion of solid feed (Jensen and Recén 1989). This contrasts with the situation in commercial pig production, where weaning is a particular critical period in the life of a piglet, involving exposure to numerous stressors at the same time. Among others, separation of piglets and sows results in a change in the piglets' diet, not only in relation to the nutritional composition but also a

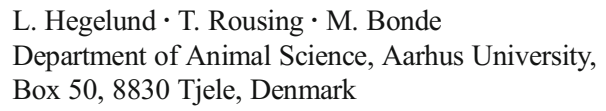

A. Sundrum
Department of Animal Nutrition and Animal Health,
University of Kassel,
Nordbahnhofstr. 1a, 37213 Witzenhausen, Germany

Present Address:

M. Bonde

Centre of Development for Outdoor Livestock Production, Marsvej 43, 8960 Randers, Denmark 
change from liquid to solid feed. The piglets are no longer protected by passive immunity from the sow's milk or by heat from the sows' body when resting. Further stressors include challenges through changes in the microbial flora in the environment, changes in climatic conditions and challenges from new physical and social environments associated with possible relocation and mixing.

There are significant differences in the management of weaning between organic and conventional pig production. The biggest of these is the age at weaning, but there are also differences in the lactation environment and the housing conditions for the newly weaned piglet. Table 1 illustrates the large diversity of weaning procedures which is present in organic pig production throughout Europe. In most organic systems, weaning is performed by physically separating the sow and piglets when the piglets are 40 days old, which is the minimum weaning age specified by Council Regulation (834/2007). In some countries, piglets are weaned at an older age dictated by national certification bodies. In addition, many organic farmers move their piglets to a different location at the time of weaning, thereby subjecting the piglets to further potential stressors such as handling, transportation and a different bacterial load. In many countries, weaners, growers and fatteners in organic systems are kept in indoor systems with access to concrete outdoor runs. Consequently, the change in environment can be rather dramatic in the systems practising outdoor farrowing and indoor weaning. Finally, weaning often involves regrouping the piglets by mixing different litters, resulting in social instability as new group hierarchies have to be formed.

This paper will review the available information on the different animal health and welfare issues in organic pigs in relation to weaning. It will address the prevalence of the most relevant health problems and will review their potential hazards and associated risk factors.

\section{Health problems}

The various weaning procedures applied across European organic pig farms predispose the weaners to different health and welfare problems. In combination with the occurrence of infectious diseases, the prevalence of diseases related to the weaning process is expected to differ considerably within and between countries. So far, only a few studies have dealt with the prevalence of

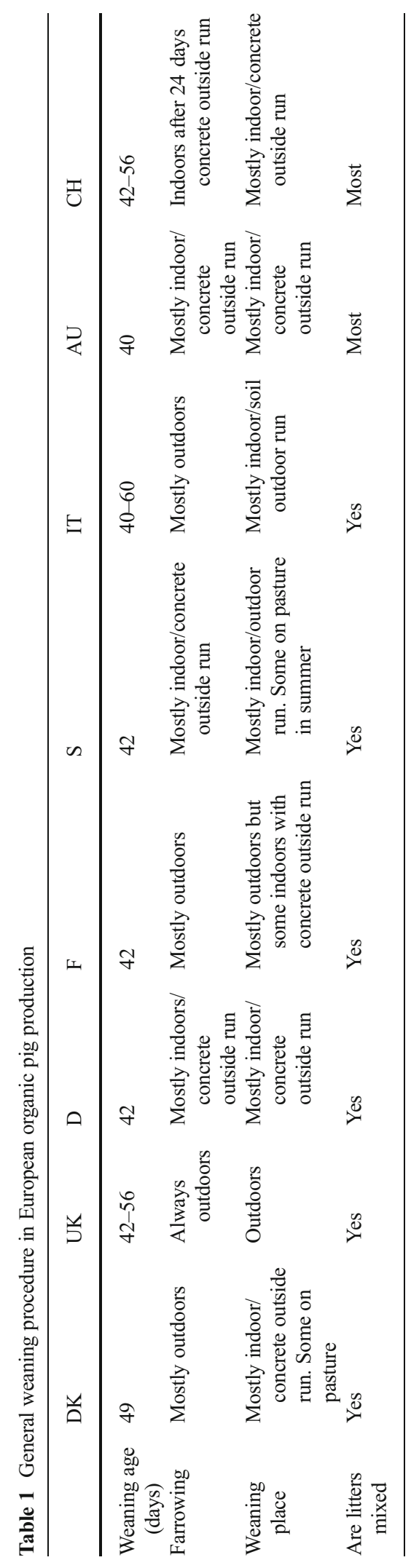


disease or welfare problems in organic weaners. In a survey including farmers from Denmark, Sweden, the Netherlands, Germany and England, the predominant health problems reported around weaning were respiratory diseases $(\mathrm{NL}, \mathrm{D}, \mathrm{DK})$, diarrhoea (D, DK, NL), arthritis (NL, D) and endoparasites (DK), while English farmers reported that insufficient feed intake is a bigger problem than infectious diseases (Bonde and Sørensen 2006). Porcine dermatitis and nephropathy syndrome, post-weaning multisystemic wasting syndrome (PMWS) and keeping the stock dry during periods of heavy rainfall were mentioned as primary concerns in another survey conducted in England (Day et al. 2003). Nordic veterinarians and advisors highlighted poor quality of feed ( $>50 \%$ of herds), lack of wallowing facilities (25-50\%), diarrhoea (25-50\%), joint infections $(<25 \%)$, meningitis $(<25 \%)$, respiratory problems $(<25 \%)$ and tail biting $(<25 \%)$ as the main health and welfare problems at this production stage (Bonde and Sørensen 2004).

\section{Post weaning diarrhoea}

Diarrhoea is a multifactorial disease, resulting from the combination of a challenged digestive system, a challenged immune system and various stressors during the weaning process. While, in the past, scientists primarily focussed on specific pathogens found in conjunction with symptoms of diarrhoea (Carpenter and Burlatschenko 2005; Jacobson et al. 2003; Wieler et al. 2001), there is increasing evidence that the presence of pathogens is only one out of a long list of factors involved (Lallès et al. 2007a,b).

Most studies concerning post-weaning diarrhoea have been performed in conventional systems, characterised by an early weaning age and by housing conditions with a high stocking density and without litter. In these studies, numerous risk factors for postweaning diarrhoea (PWD) have been identified as follows: 'pre-weaning diarrhoea', 'larger litters', 'low weaning weight', 'low weaning age', 'low creep feed intake', 'cleanliness of the weaning pen', 'temperature of the weaning pen', 'air quality', group size', 'stocking procedure', and 'feed intake of the piglets during the first week post weaning' (Svensmark et al. 1989; Madec et al. 1998; Skirrow et al. 1997). In conventional systems, weaning diarrhoea is seen 3-10 days after weaning, typically involving proliferation of haemolytic Escherichia coli (Carstensen et al. 2005). Often multiple concurrent pathogens are involved. Differential diagnoses for diarrhoea in weaned pigs include salmonellosis, swine dysentery, porcine proliferative enteropathy caused by Lawsonia intracellularis, rotavirus and coronavirus enteritis, post-weaning colibacillosis, trichuriasis, coccidiosis and porcine colonic spirochetosis caused by Brachyspira pilosicoli (Carpenter and Burlatschenko 2005). The symptoms are not confined to the gut but can overlap with disturbances of other organs and tissues. According to Svensmark et al. (1989), diarrhoea is often associated with an increased incidence of diseases of the skin and respiratory tract.

On six organic farms affected with PWD problems, laboratory analyses provided proof for the presence of different strains of haemolytic E. coli, B. pilosicoli and L. intracellularis, however, independent of the health status of the piglets (Sundrum et al. 2010). The examination of critical control points revealed that all affected farms showed more or less severe deficiencies in the hygiene management and in the nutrient regime.

In the study of Bussemas and Weissmann (2008), an extended suckling period of 63 days resulted in an improved growth rate and in a reduced number of medically treated piglets, while the prolongation did not negatively affect the body and teat condition of the sow.

Under semi-natural conditions, weaning is a gradual process where the piglets' suckling frequency decreases as milk is substituted by solid food. This process is completed when the piglets are 10-19 weeks old (Jensen and Recén 1989). As the intake of solid feed increases, the piglets' intestinal system is matured with regards to the microbial colonisation and the gastrointestinal physiology and morphology (as reviewed by Lallès et al. 2007a).

A well-documented consequence of an early and abrupt weaning is a temporarily reduced intestinal digestion and absorption, which increases the risk of postweaning diarrhoea (Pluske et al. 1997). The piglet's immune system develops in successive stages, and among the later components is $\operatorname{IgA}^{+}$(Lallès et al. 2007b), which acts to protect against E. coli. These developmental issues, which can cause problem with early weaning, are amply documented in conventional systems, where the weaning age is $21-28$ days. Although risk of post weaning diarrhoea has been shown to decrease with increasing weaning weight and age (Madec et al. 1998), the minimum weaning age of 40+ days in organic systems is still considerably earlier than under semi-natural conditions and thus at least some of 
the developmental/maturity problems are likely to still be of relevance.

\section{Cold stress}

Another potential welfare implication of weaning, especially during cold seasons, is thermal discomfort when the piglets cannot benefit from the heating capacity of the sow's body heat. This is a likely reason for the regional differences seen in weaning systems with respect to whether weaners are kept inside or outside. In general, the southern European countries wean outdoors while northern European countries, except UK, wean into indoor systems with outdoor runs. A problem with keeping the outdoor stock dry during periods of heavy rainfall was mentioned as a primary concern in a survey conducted in England (Day et al. 2003). The reduced feed intake which occurs when the piglet is forced to make an early transition from milk to a diet with only solid feed results in an increase in the lower critical temperature and hence greater susceptibility to cold stress. Whilst a later weaning age reduces the extent of this deficit in energy intake, it has still been shown to occur when piglets are weaned at 6 weeks of age (Wellock et al. 2007) and may be more marked if the feed is of lower nutrient density and palatability, as can be the case in some organic systems because of limitations on permitted ingredients.

\section{Skin lesions}

Skin lesions are generally indicative of social disruption within the group. Comparison of skin lesions on body, ear and tail on days 5 and 28 after weaning shows significantly more skin lesions on the body of weaners in mixed groups compared to groups consisting of littermates (Baumgartner 2007).

Other health problems

No published data have been found on the prevalence of respiratory diseases and arthritis in organic weaned piglets.

\section{Endoparasites}

Parasites of importance for weaners are primarily Ascaris and Trichuris. Piglets born in farrowing crates with solid flooring and straw bedding may have been exposed to many Ascaris eggs, while piglets born on pastures may have been exposed to both helminths. Piglets may have many immature worms already from the first few weeks of life (Roepstorff and Mejer, unpublished). These worms may reach adulthood during the first 2-4 weeks after weaning at 7 weeks of age, where after worm eggs in faeces can be demonstrated using standard diagnostic techniques. In traditionally managed indoor herds, weaners have been shown to have $54 \%$ Ascaris and $3 \%$ Trichuris in Denmark (Roepstorff 1991), 12 and $0 \%$ in France (Raynaud et al. 1975), 16 and $24 \%$ in UK (Pattison et al. 1980).

In intensive indoor herds, there is almost no helminth transmission in the farrowing pens, irrespective of whether the sows excrete eggs or not, which has been attributed to a very dry microclimate (Roepstorff 1997). The prevalences of Ascaris in 10-12-week-old weaners in Denmark have thus been found to vary with the production system, being $1 \%$ in intensive indoor herds (conventional), $10 \%$ in traditional indoor herds (conventional), $50 \%$ in pioneering organic herds and $28 \%$ in second generation organic herds, respectively (Roepstorff et al. 1998; Roepstorff et al. 1992; Carstensen et al. 2002). In comparison, $67 \%$ of 8-12week-old pigs were positive for Ascaris in Swedish outdoor herds (Christensson 1996), whereas organic weaners in a Dutch study were at the borderline of being too young to have detectable patent infections (Eijck and Borgsteede 2005). Even though the more professional management within Danish organic herds thus seems to have reduced the prevalence of Ascaris in weaners from 1991-1992 to 2000, this age group is still heavily infected. This may in part reflect that some Ascaris eggs may survive for 9 years on pastures (Krasnonos 1978) and exposure is thus impossible to avoid if pigs are born outside and permanent pastures are used or pasture rotation schemes are too short.

Trichuris is primarily found in weaners born on pastures, as transmission of this parasite is very poor indoors, whereas its eggs may survive for up to 11 years in soil (Burden et al. 1987). As pigs do acquire a very strong resistance, Trichuris usually only have a restricted period of egg excretion, varying from 5-8 weeks, before the worms are completely expelled (Roepstorff and Murrell 1997; Pedersen and Saeed 2001; Kringel and Roepstorff 2006). In pioneering organic herds in Denmark, only 1 herd out of 12 was heavily infected (weaner prevalence $79 \%$, Roepstorff et al. 1992), while 
2 out of 9 of the second generation organic herds had highly infected weaners (10-50\%, Carstensen et al. 2003). Similarly, weaners from one of ten Swedish outdoor farms were positive for Trichuris (Christensson 1996). It is notable that all heavily infected Danish herds were established $\geq 5$ years before the study, which means that Trichuris eggs had time to accumulate in the soil and that the pigs may have had the opportunity to return to previously contaminated areas.

Werner et al. (2009) conducted a study to assess the hygienic measures used on organic pig farms and to evaluate their effectiveness in reducing endoparasite infections on 20 organic pig-breeding farms in Germany. Management factors related to helminth infections of the herds were recorded in personal interviews. The majority of the farrowing units $(n=15)$ were cleaned wet, whereas most of the farmers did not clean the gestation pens at all and, if so, only mechanically by removing dung. Chemical disinfection was only performed in farrowing units in at most $20 \%$ of the farms. Strongylid, Trichuris suis and Ascaris suum eggs were detected in 78.5, 2.8 and $1.3 \%$, respectively. Regarding the worm control and hygiene management, there were no differences between strongylid free or infected farms. Thus, those farms who used comprehensive hygiene measures were not necessarily gaining the best results with respect to endoparasite infection. The authors concluded that, without the implementation of a strategic control and feedback mechanism within the production process, effectiveness of hygiene measures related to worm burden cannot be assessed sufficiently.

Post-weaning multisystemic wasting syndrome

PMWS is a disease that affects weaned pigs, mainly between 6 and 14 weeks of age. It has variable clinical signs including loss of condition, pallor, depression, laboured breathing, fever, inappetence and enlarged peripheral lymph nodes. Mortality rates of up to $20 \%$ are common during the early stages of the disease. The cause has not been completely defined, but there is an association with the porcine circovirus2. Although it has been suggested that later weaning may reduce the prevalence of clinical problems, PMWS has been reported as a significant problem on a number of organic units (Day et al. 2003; SAC Veterinary Services 2006).

\section{Distress and frustration}

Separation from the mother

Andersen et al. (1999) reported that belly nosing behaviour was initiated a short time after weaning and that the frequency increased during the following weeks. Additionally, these authors found that aggression increases after weaning (Andersen et al. 1999; Fraser 1978). These behavioural changes indicate that weaned piglets experience distress or frustration due to an unsatisfied motivation to suckle (Van Putten and Dammers 1976; Fraser 1978), social factors (Petersen et al. 1995) or a restrictive environment (Dybkjær 1992). As mentioned above, piglets may experience a range of stressors when weaned. Compared to natural conditions, weaning is an abrupt and premature termination of the mother-offspring relationship. Typically, weaners are additionally moved to other housing systems - some from outdoor to indoor systems - increasing the risk of experiencing distress due to handling, transport, and a new environment, and finally mixing of litters is a frequently used procedure increasing the risk of social competition. Depending on the exact weaning procedure, the welfare implications of weaning can be increased stress responsiveness, frustration, aggression or development of stereotypic behaviour (as discussed by Latham and Mason 2008; Weary et al. 2008). The lactation environment in itself can further influence the welfare implications of weaning, as animals reared in more enriched environments tend to be better capable of coping with weaning (Hötzel et al. 2004; O'Connel et al. 2005).

New environment

The transport and new housing facilities that many piglets experience when weaned constitute additional stressors. Studies have shown that newly weaned piglets (42 days) have more problems coping with unfamiliar housing than coping with unfamiliar piglets (Puppe et al. 1997). Donaldson et al. (2002) reported depression in play during the first days after weaning (in pigs weaned at 24 days). Organic standards require that weaned piglets have bedding and an outside area, providing a greater degree of enrichment than experienced by many conventional weaners. Millet et al. (2005) pointed out in a review that, in general, non-conventional housing has several advantages due to such access to straw and a generally higher enrichment level. 


\section{Mixing}

Often weaning involves regrouping the piglets by mixing different litters to give larger or less variable groups, and this can temporarily affect the piglet welfare as the level of aggression is increased when unfamiliar piglets are mixed (Puppe et al. 1997; Friend et al. 1983). The aggression and associated injuries can be reduced if piglets are mixed in the suckling period (Pitts et al. 2000; Weary et al. 2002) when they more easily form new social hierarchies (D'Eath 2005). Also, the physical environment during lactation affects the behaviour of piglets when mixed, as several studies point to a lower level of aggression when mixing piglets reared outside or in enriched pens (Cox and Cooper 2001; Weary et al. 2008). This can be a consequence of specific social skills learned by the piglets when intermingling with other older and younger litters, or due to improved capacity to cope with novel challenges in animals exposed to a more complex social and physical environment (as discussed by Cox and Cooper 2001). In many outdoor farrowing systems, the piglets benefit from an enriched environment and they are capable of moving between paddocks, thereby becoming familiarised with other litters before weaning.

\section{Fear of humans}

Fear of humans, as measured by a human approach test, is significantly lower in piglets weaned at 7 weeks compared to piglets weaned at 5 weeks (Andersen et al. 1999). The later weaning age in organic systems might therefore be beneficial.

Hazards and risk factors for health and welfare in organic weaners

Weaning exposes the piglets to numerous, presumably interacting, stressors at the same time, potentially resulting in one or more of the abovementioned problems. In the following section, the potential hazards of the different problems are therefore addressed in a summarised way, and the potential animal, housing, nutritional and management-related risk factors are discussed.

Animal

The major animal-related risk factor for health and welfare problems in organic weaners would appear to be weaning age. This affects many different hazards, as described in the following section. Information on the effect of other animal characteristics, such as breed, is lacking.

\section{Housing system}

Organic weaners must be housed with bedding and with outdoor access. The benefits of outdoor access for weaners, either to fresh air in concrete outruns or full access to soil at pasture, have not been well studied. Data from UK conventional herds suggest that outdoor rearing, in huts with runs, gives better health and performance, but these data may be confounded by the origin of the pigs (BPEX 2005).

The provision of bedding provides benefits for foot and leg health, through cushioning properties, for thermal comfort, through insulation properties and for environmental enrichment. Kelly et al. (2000a) compared three types of flooring for weaners as follows: galvanised expanded metal floors, a system with solid concrete floor and minimal straw cover and deep straw. It was found that weaned piglets, with existing foot injuries from the farrowing house floor, recovered quickly in deep bedded pens. The authors concluded from the experiments that solid floors, particularly with bedding, benefit welfare since fewer foot injuries were recorded. With weaners, appetitive behaviour directed at the belly of other piglets, known as belly-nosing, as well as other oral behaviour directed at pen mates, are also reduced if they are offered straw (McKinnon et al. 1989; Kelly et al. 2000b). Furthermore, Zonderland et al. (2008) demonstrated a reduced prevalence of tail biting in weaners when straw was present.

However, the use of bedded systems may also pose an increased risk for development and spread of enteric disease. Experiments on conventional pigs conducted in Sweden (Holmgren and Lundeheim 1994; Rantzer and Svendsen 2001) showed that pigs housed in pens with solid floors lived in dirtier pens with much higher bacterial counts, and had greater prevalence of diarrhoea. PMWS was found to have more severe expression in a straw-based housing system with solid floors compared to a system with conventional fully-slatted floors (Scott et al. 2006). Parasite persistence and transmission is also greater in bedded systems. The hygiene management in bedded systems is therefore of critical importance. 
Nutrition and feeding

\section{Thirst and hunger}

Suckling piglets rely primarily on milk as a source of nutrients, energy and water. In farm practise, the feeding regime and nutrient supply before and after weaning varies to a high degree between farms. While in many farm systems piglets go through a period of anorexia immediately after weaning, farms may provide a restricted ration or feed the piglets ad libitum. Also, the diet composition can vary across a wide range from lowquality feed with respect to the digestibility, to special diets exclusively composed to help the piglets through this critical life stage. Thus, change of the diet from milk to solid feed can be associated with more or less weaning distress. Beside the intake of solid feed, the piglets must learn to recognise and drink water when weaned. A change in type of water dispenser at weaning to a nipple or bite drinker can result in a temporary decrease in water consumption, although unhygienic troughs are avoided in such systems (Phillips and Phillips 1999; Sørensen et al. 1994). Furthermore, the drinking behaviour is influenced when piglets are mixed with unfamiliar litters (Dybkjær et al. 2006).

\section{Feed consumption}

Early food consumption after weaning is generally considered essential for maintaining gut function in weaned piglets (Kuller et al. 2007). Several studies show that a high post-weaning feed intake lowers the risk of PWD (Callesen et al. 2007; Madec et al. 1998; Skirrow et al. 1997). An experimental study of piglets inoculated with E. coli $\mathrm{O} 149$ and weaned at 7 weeks showed that a feed intake of less than $200 \mathrm{~g}$ on day 1 after weaning was associated with a high incidence of a post-weaning diarrhoea-like condition (Sørensen et al. 2009).

However, beside the variation in feeding regime and diet composition, a group of piglets is not homogenous. Correspondingly, feed intake behaviour varies considerably between piglets. Sub-optimal conditions are more likely to result in a depressed feed intake in weaned piglets than in older pigs and sub-optimal feed intake of the group will result in under-nutrition for a number of piglets within the group (Hees et al. 2004).

Whether or not an irregular feed intake will cause diarrhoea is determined by a large number of feed and environmental factors. Overfeeding and irregular feed intake may lead to a diminished digestibility and may result in intestinal disorder and diarrhoea. A low feed intake immediately after weaning, preventing an excess of poorly digested material in the gut, can also provide beneficial effects when trying to prevent PWD (Carstensen et al. 2005). In studies of Taina et al. (2008), an increased risk of PWD was associated with the regimen of twice a day feeding and feed restriction after weaning compared to feeding three or more smaller meals a day or the use of ad libitum feeding. The postweaning consumption is influenced by weaning age (as reviewed by Weary et al. 2008), pre-weaning creep feed intake (Bruininx et al. 2002; Kuller et al. 2007; Carstensen et al. 2005) and housing conditions for the suckling piglets. Avoidance of mixing and undisturbed easy access to food and water is beneficial to both health and welfare of piglets, as well as their productivity (Horvath et al. 2000).

Achieving high intakes before weaning, to the extent that the piglets are partially or fully established on solid feed, can reduce distress responses to separation from the sow. Studies with early weaned piglets have shown that creep feed intake during the suckling period stimulates early post-weaning intake (Bruininx et al. 2002). Creep feed intake during the suckling period also enhances net absorption in the small intestine after weaning, which provides a useful tool in the prevention of post-weaning diarrhoea (Kuller et al. 2007).

The quality of the diet (Pajor et al. 2002, cited in Weary et al. 2008), taste/flavour (Langendijk et al. 2007) and design of the feeder (Appleby et al. 1992) are all important for enhancing food consumption after weaning. Piglets eat more creep feed from a tray feeder than a hopper feeder, while no significant effect of sow feeding method on piglet creep feed intake was demonstrated (Wattanakul et al. 2005). The authors concluded that the method of presentation is less relevant for the total feed intake but very important in the initiation of feeding behaviour.

\section{Diet composition}

As reviewed by Lallès et al. (2007b), the diet composition is one of the key factors in controlling weaning diarrhoea. Many studies performed under conventional conditions point to the importance of various amino acids, dietary fibres, fermentable carbohydrates, lactobacilli, bifidobacilli, yeasts and plant/herb extracts 
for either prevention or cure. However, in the numerous investigations that have been conducted on varying diet composition, or supplementing with different substances of animal or plant origin, positive effects on the gut have often been variable and sometimes inconsistent (Lallès et al. 2007a).

Organic pig production has to face severe restrictions in the availability of feedstuffs with high quality protein. Organic farmers often make use of home-grown cereals and grain legumes to formulate farm-specific diets (Dietze et al. 2007). Different legume protein sources vary considerably in relation to their impacts on nutrient digestibility, intestinal morphology and digestive enzyme activity in weaned piglets (Salgado et al. 2002). The protein profile of legume seeds is characterised by a relative deficiency in sulphur amino acids and tryptophan and by the presence of antinutritional factors (ANF; e.g. protease inhibitors, lectins, tannins or alkaloids) (Gatel 1994). ANFs can be responsible for a reduced feed intake and a lower digestibility, which can also be partly explained by reduced accessibility of legume seed protein to digestive enzymes (Godfrey et al. 1985; Gatel 1994). Due to the restricted availability of feedstuffs with a high content of limiting amino acids and a high digestibility, growth rates and protein accretion are clearly lower in organic compared to conventional production (Sundrum et al. 2005). Within the organic framework conditions, different measures are at the farmer's disposal to optimise the use of limited resources and to adapt the supply of limited amino acids to the growth process.

In an experimental study of piglets inoculated with $E$. coli $\mathrm{O} 149$ and weaned at 7 weeks, 'feed restriction' and 'diet including lupines as a protein source' had no effect on faecal consistency while 'protein restriction' increased faecal dry matter (Sørensen et al. 2009). While case studies have shown a positive effect of vitamin $E$ in terms of reducing weaning diarrhoea (Lamberts 1997), studies in organic systems supply no evidence that providing extra vitamin $\mathrm{E}$ in the diet reduces incidence of post-weaning diarrhoea (Sørensen et al. 2009; Sørensen et al. 2005).

A high portion of home-grown feedstuffs, which may be harvested or stored in suboptimal conditions, possibly implies a higher risk for the presence of mycotoxins in the diet. Low doses of mycotoxins are able to depress growth and alter many aspects of humoral and cellular immunity in weanling piglets (Marin et al. 2002).

\section{Management}

In a questionnaire survey to advisors and veterinarians in Nordic organic systems, 'insufficient cleaning of outdoor run' was suggested as the main cause of diarrhoea, while 'insufficient daily cleaning', 'insufficient cleaning between groups', 'common shared cleaning path between pens', 'possibility for contact between pens', 'insufficient nutrient composition of feed' and 'no opportunity for restrictive feeding' were other important causes. Additionally, 'poor hygienic quality of feed and water' and 'too few drinking places' were contributory causes (Bonde and Sørensen 2004). In various studies, the occurrence of post-weaning diarrhoea has been associated with poor pen hygiene (Rantzer and Svendsen 2001; Madec et al. 1998). Onfarm assessments on organic pig farms often revealed suboptimal hygiene conditions and deficiencies in the hygiene management and in the nutrient regime, although varying in their details considerably between the farms (Dietze et al. 2007). Thus, effective clinical management of PWD includes the identification of risk factors and the implementation of changes aimed at reducing the incidence. The development of diagnostic tools to be used at the farm level should be encouraged to enable appropriate and prompt counteractive measures.

\section{Conclusions}

Diseases around weaning are multifactorial in nature. In general, not one but several factors are in place, simultaneously imposing stressors at weaning. The number of possible combinations of stressors, which additionally vary considerably in their extent and pathogenic capacity, are unlimited. The identification of the main stressors supports the interpretation of the farm-specific situation. However, trying to disentangle the various factors by a mono-causal approach can much diminish the combined response.

There is a need for improved diagnostic measures at farm level and for preventive and curative measures that are closely related to the farm-specific situation. The complexity and the individuality of farm systems need to be taken into account. Within a system approach, 
animal health plans can be developed as a suitable framework with feedback mechanisms. Consequently, there is a need for a change in the paradigm from a standard-oriented to an output-oriented approach.

Acknowledgments The study was part of the ERA-net CORE Organic project COREPIG (http://corepig.coreportal.org). The authors wish to thank all national funders for their financial support.

\section{References}

Andersen L, Jensen KK, Jensen KH, Dybkjær L, Andersen BH (1999) Weaning age in organic pig production. In Hermansen JE, Lund V Thuen E (eds.) Ecological Animal Husbandry in the Nordic Countries. Proceeding from NJF-seminar No. 303, Horsens, Denmark, Sept. 1999, 119-123

Appleby MC, Pajor EA, Fraser D (1992) Individual variation in feeding and growth of piglets: effects of increased access to creep food. Anim Prod 55:147-152

Baumgartner J (2007) How to deal with complex data of skin lesions in weaner pigs. Anim Welf 16:165-168

Bonde M, Sørensen JT (2004) Velfærds- og sundhedsproblemer i økologisk sohold: forekomst, risikofaktorer og kontrolmuligheder. FØJO Intern rapport nr. 54. 200: Produktionsstyring med fokus på husdyrsundhed og fødevaresikkerhed i økologiske svinebesætninger. 7-18. Organic eprint nr. 3236

Bonde M, Sørensen, J.T. (2006): Animal health and welfare in organic European pig production: State of the art and challenges for the future, based on a North-western European questionnaire survey. Proceedings of the European Joint Organic Congress. 2006. 562-563

Bruininx EMAM, Binnendijk GP, van der Peet-Schwering CMC, Schrama JW, den Hartog LA, Beynen AC (2002) Effect of creep feed consumption on individual feed intake characteristics and performance of group-housed weanling pigs. J Anim Sci 80:1413-1418

Burden DJ, Hammet NC, Brookes PA (1987) Field observations on the longevity of Trichuris suis ova. Vet Rec 121:43

Bussemas R, Weissmann F (2008) Prolonged suckling period in organic piglet production - Effects on some performance and health aspects. 2nd Conference of the International Society of Organic Agriculture Research ISOFAR, Modena, Italy, June 18-20, p. 148

Callesen J, Halas D, Thorup F, Bach Knudsen KE, Kim JC, Mullan BP, Hampson DJ, Wilson RH, Pluske JR (2007) The effects of weaning age, diet composition, and categorisation of creep feed intake by piglets on diarrhoea and performance after weaning. Livest Sci 108:120-123

Carpenter JA, Burlatschenko S (2005) Diarrhea in nursery pigs associated with multiple concurrent pathogens. J Swine Health Prod 13(4):218-221

Carstensen L, Ersboll AK, Jensen KH, Nielsen JP (2005) Escherichia coli post-weaning diarrhoea occurrence in piglets with monitored exposure to creep feed. Vet Microbiol 110(1-2):113-123

Carstensen L, Vaarst M, Roepstorff A (2002) Helminth infections in Danish organic swine herds. Vet Parasitol 106:253-264

Carstensen L, Roepstorff A, Vaarst M (2003) Endoparasitter I økologiske svinebesætninger. Danmarks JordbrugsForskning, Husdyrbrug 49:40

Christensson D (1996) Djurmiljö och parasitförekomst i utegrishållning - inventering på 12 gårdar. Jordbruksinformation 5:26-27

Council Regulation (EC) No 834/2007 of 28 June 2007 on organic production and labelling of organic products and repealing Regulation (EEC) No 2092/91

Cox LN, Cooper JJ (2001) Observations on the pre- and postweaning behaviour of piglets reared in commercial indoor and outdoor environments. Anim Sci 72:75-86

Day JEL, Kelly H, Martins A, Edwards SA (2003) Towards a baseline assessment of organic pig welfare. Anim Welf 12:637-641

Dietze K, Werner C, Sundrum A (2007) Status quo of animal health of sows and piglets in organic farms. In: Niggli, U. Leiffert, C. Alföldi, T. Lück, L., Willer, H. (eds.), Improving sustainability in organic and low input food production systems. Proc. 3rd QLIF Congress, Hohenheim, Germany, March 20-23, 2007, 366-369

D'Eath RB (2005) Socialising piglets before weaning improves social hierarchy formation when pigs are mixed postweaning. Applied Animal Behaviour Sci 93:199-211

Donaldson TM, Newberry RC, Spinka M, Cloutier S (2002) Effects of early play experience on play behaviour of piglets after weaning. Appl Anim Behav Sci 79(3):221-231

Dybkjær L (1992) The identification of behavioural indicators of 'stress' in early weaned piglets. Appl Anim Behav Sci 35:135-147

Dybkjær L, Jacobsen AP, Tøgersen FA, Poulsen HD (2006) Eating and drinking activity of newly weaned piglets: effects of individual characteristics, social mixing, and addition of extra zinc to the feed. J Anim Sci 84:702-711

Eijck IA, Borgsteede FH (2005) A survey of gastrointestinal pig parasites on free-range, organic and conventional pig farms in The Netherlands. Vet Res Commun 29:407-441

Fraser D (1978) Observations on the behavioural development of suckling and early-weaned piglets during the first six weeks after birth. Animal Behaviour 26 (1):22-30

Friend TH, Knabe DA, Thanksley TD Jr (1983) Behaviour and performance of pigs grouped by three different methods at weaning. J Anim Sci 5786:1406-1411

Gatel F (1994) Protein quality of legume seeds for non-ruminant animals: a literature review. Anim Feed Sci Technol 45:317348

Godfrey NW, Mercy AR, Emms Y, Payne HG (1985) Tolerance of growing pigs to lupin alkaloids. Aust J Exp Agric 25:791-795

Hees van H, Vente-Spreeuwenberg M., Gils van B (2004): Managing feed intake of weaned piglets: Interactions between nutrition, ethnology and farm management. In. Garnsworthy, P.C., Wiseman, J. (eds.): Recent advances in animal nutrition. Nottingham University Press, p. 9-40

Hötzel MJ, Machado LCP, Wolf FM, Costa OAD (2004) Behaviour of sows and piglets reared in intensive outdoor or indoor systems. Applied Animal Behaviour Sciences 86:27-39

Holmgren N, Lundeheim N (1994) Djurhälsomässiga behovet av fodermedelsantibiotika i smägrisproducerande besättningar. Svensk Vet Tidn 46:57-65 
Horvath G, Jaczkone Jarabin I, Visnyei L (2000) Effects of regrouping, feeding and drinking methods on weight gain of weaned piglets. Dtsch tierärztl Wschr 107:364-367

Jacobson M, Hård Af Segerstad C, Gunnarsson A, Fellström C, De Verdier Klingenberg K, Wallgren P, Jensen-Waern M (2003) Diarrhoea in the growing pig - a comparison of clinical, morphological and microbial findings between animals from good and poor performance herds. Res Vet Sci 74:163169

Jensen P, Recén B (1989) When to wean - observations from freeranging domestic pigs. Applied animal behaviour science 23(1-2):49-60

Kelly HRC, Bruce JM, English PR, Fowler VR, Edwards SA (2000a) Behaviour of 3-week weaned pigs in straw-flow, deep straw and flatdeck housing systems. Appl Anim Behav Sci 68:269-280

Kelly HRC, Bruce JM, Edwards SA, English PR, Fowler VR (2000b) Limb injuries, immune response and growth performance of early-weaned pigs in different housing systems. Anim Sci 70:73-83

Krasnonos LN (1978) Prolonged survival of Ascaris lumbricoides L., 1758 ova in the soil in Samarkand. Meditsinskaya Parazitologicya i Parasitaryne Bolezni 47:103-105

Kringel H, Roepstorff A (2006) Trichuris suis population dynamics following a primary experimental infection. Vet Parasitol 139:132-139

Kuller WI, Soede NM, van Beers-Schreurs HMG, Langendijk P, Taverne MAM, Kemp B, Verheijden JHM (2007) Effects of intermittent suckling and creep feed in take on pig performance from birth to slaughter. J Anim Sci $85: 1295-1301$

Kuller WI, van Beers-Schreurs HMG, Soede NM, Langendijk P, Taverne MAM, Kemp B, Verheijden JHM (2007) Creep feed intake during lactation enhances net absorption in the small intestine after weaning. Livest Sci 108: 99-101

Lallès J-P, Bosi P, Smidt H, Stokes CR (2007a) Weaning-a challenge to gut physiologists. Livest Sci 108:82-93

Lallès J-P, Bosi P, Smidt H, Stokes CR (2007b) Nutritional management of gut health in pigs around weaning. Proceeding of the Nutrition Society 66:260-268

Lamberts FJ (1997) Vitamin E as a potential agent to control diseases on pig farms: a field trial. Tijdschrift voor diergeneeskunde 122(7):190-192

Langendijk P, Bolhuis JE, Laurenssen BFA (2007) Effects of preand postnatal exposure to garlic and aniseed flavour on preand post-weaning feed intake in pigs. Livest Sci 108:284-287

Latham NR, Mason GJ (2008) Maternal deprivation and the development of stereotypic behaviour. Appl Anim Behav Sci 110 (1-2):84-108

Madec F, Bridoux N, Bounaix S, Jestin A (1998) Measurement of digestive disorders in the piglet at weaning and related risk factors. Preventive Veterinary Medicine 35:53-72

Marin DE, Taranu I, Bunaciu RP, Pascale F, Tudor DS, Avram N, Sarca M, Cureu RD, Suta V, Oswald IP (2002) Changes in performance, blood parameters, humoral and cellular immune responses in weanling piglets exposed to low doses of aflatoxin. J Anim Sci 80:1250-1257

McKinnon AJ, Edwards SA, Stephens DB, Walters DE (1989) Behaviour of groups of weaner pigs in three different housing systems. Br Vet J 145:367-372
Millet S, Raes K, Van den Broeck W, De Smet S, Janssens GPJ (2005) Performance and meat quality of organically versus conventionally fed and housed pigs from weaning till slaughtering. Meat Sci 69:335-341

O'Connel NE, Beattie VE, Sneddon IA, Breuer K, Mercer JT, Rance KA, Sutcliffe MEM, Edwards SA (2005) Influence of individual predisposition, maternal experience and lactation environment on the responses of pigs to weaning at two different ages. Appl Anim Behav Sci 90:219-232

Pajor EA, Weary DM, Caceres C, Fraser D, Kramer DL (2002) Alternative housing for sows and litters part3. Effects of piglet diet quality and sow-controlled housing on performance and behaviour. Appl Anim Behav Sci 76:267-277

Pattison HD, Thomas RJ, Smith WC (1980) A survey of gastrointestinal parasitism in pigs. Vet Rec 107:415-418

Pedersen S, Saeed I (2001) Acquired immunity to Trichuris suis infection in pigs. Parasitology 123:95-101

Petersen V, Simonsen B, Lawson G (1995) The effect of environmental stimulation on the development of behaviour in pigs. Appl Anim Behav Sci 45:215-224

Pitts AD, Weary DM, Pajor EA, Fraser D (2000) Mixing at young ages reduces fighting in unacquainted domestic pigs. Appl Anim Behav Sci 68:191-197

Phillips PA, Phillips MH (1999) Technical notes: effect of dispenser on water intake of pigs at weaning. Transactions of the ASAE 42(5):1471-1473

Pluske JR, Hampson DJ, Williams IH (1997) Factors influencing the structure and function of the small intestine in the weaned pig: a review. Livest Prod Sci 51:215-236

Puppe B, Tuchscherer M, Tuchscherer A (1997) The effect of housing conditions and social environment immediately after weaning on the agonistic behaviour, neutrophil/lymphocyte ratio and plasma glucose level in pigs. Livestock production science 48:157-164

Rantzer D, Svendsen J (2001) Slatted versus solid floors in the dung area: comparison of pig production system (moved versus not moved) and effects on hygiene and pig performance, weaning to 4 weeks after weaning. Acta Agric. Scand. Sect A, Animal Sci 51:175-183

Raynaud J-P, Sennelier J, Irisarri E (1975) Contamination parasitaire des porcelet après leur naissance au contact de meres infestees. Etudes sur 20 truies et 164 porcelets dont 42 sacrifies au sevrage. Folia Veterinaria Latina 5: 412-429

Roepstorff A (1991) Transmission of intestinal helminths in Danish sow herds. Vet Parasitol 39:149-160

Roepstorff A (1997) Helminth surveillance as a prerequisite for anthelmintic treatment in intensive sow herds. Vet Parasitol 73:139-151

Roepstorff A, Jørgensen RJ, Nansen P, Henriksen SA, Skovgaård Pedersen J, Andreasen M (1992) Parasitter hos økologiske svin. Report paper from a project financed by the Danish Ministry of Agriculture. Landsudvalget for svin, Danske Slagterier, Copenhagen, p 36

Roepstorff A, Murrell KD (1997) Transmission dynamics of helminth parasites of pigs on continuous pasture: Ascaris suum and Trichuris suis. Int J Parasitol 27:563-572

Roepstorff A, Nilsson O, Oksanen A, Gjerde B, Richter SH, Örtenberg E, Christensson D, Martinsson KB, Bartlett PC, Nansen P, Eriksen E, Helle O, Nikander S, Larsen K (1998) Intestinal parasites in swine in the Nordic countries: 
prevalence and geographical distribution. Vet Parasitol 76: 305-319

SAC Veterinary Services (2006) Vet Rec 159:729-732

Salgado P, Freire JB, Mourato M, Cabral F, Toullec R, Lallès JP (2002) Comparative effects of different legume protein sources in weaned piglets: nutrient digestibility, intestinal morphology and digestive enzymes. Livest Prod Sci 74: 191-202

Scott K, Chennells DJ, Campbell FM, Hunt B, Armstrong D, Taylor L, Gill BP, Edwards SA (2006) The welfare of finishing pigs in two contrasting housing systems: Fullyslatted versus straw-bedded accommodation. Livest Sci 103:104-11

Skirrow SJ, Buddle JR, Mercy AR, Madec F, Nicholls RR (1997) Epidemiological studies of pig diseases. 2. Post-weaning diarrhoea and performance in western Australian pigs. Australian Veterinaary Journal 75(4):282-288

Sundrum A., Goebel A., Werner C. (2010): Diagnostic of postweaning diarrhoea on the farm level. 21st Congress of the Int. Pig Veterinary Society (IPVS), July 18-21, Vancouver, Canada

Svensmark B, Nielsen K, Willeberg P, Jorsal SE (1989) Epidemiological studies of piglet diarrhoea in intensively managed Danish sow herds. II Post-weaning diarrhoea. Acta vet scand 30(1):55-62

Sørensen MT, Vestergaard E-M, Jensen SK, Lauridsen C, Højsgaard S (2009) Performance and diarrhoea in piglets following weaning at seven weeks of age: challenge with $E$. coli $\mathrm{O} 149$ and effect of dietary factors. Livest Sci 123:314 321

Sørensen MT, Rasmussen J, Vestergaard E-M, Jensen SK (2005) E-vitamin til økologiske smågrise efter fravænning. Grøn Viden, Husdyrbrug nr. 45, Dec. 2005

Sørensen MT, Jensen BB, Poulsen HD (1994) Nitrate and pig manure in drinking water to early weaned piglets and growing pigs. Livest Prod Sci 39(2):223-227
Taina ML, Lyytikäinen T, Yliaho M, Anttila M (2008) Risk factors for post-weaning diarrhoea on piglet producing farms in Finland. Acta Vet Scand 50:21

Van Putten G, Dammers J (1976) A comparative study of the wellbeing of piglets reared conventionally and in cages. Appl Anim Ethol 2:339-356

Wattanakul W, Bulman CA, Edge HL, Edwards SA (2005) The effect of creep feed presentation method on feeding behaviour, intake and performance of suckling piglets. Applied animal behaviour Science 92:27-36

Weary DM, Pajor EA, Bonenfant M, Fraser D, Kramer DL (2002) Alternative housing for sows and litters. part 4. Effects of sow-controlled housing combined with a communal piglet area on pre- and post-weaning behaviour and performance. Appl Anim Behav Sci 76:279-290

Weary DM, Jasper J, Hötzel ML (2008) Understanding weaning distress. Appl Anim Behav Sci 110:24-41

Wellock IJ, Fortomaris PD, Houdijk JGM, Kyriazakis I (2007) Effect of weaning age, protein nutrition and enterotoxigenic Escherichia coli challenge on the health of newly weaned piglets. Livest Sci 108:102-105

Werner C, Goebel A, Sundrum A (2009) Relationship between hygiene management and endoparasite infections in 20 sow herds. Proceedings of the XIV ISAH-Congress 2009 (International Society of Animal Hygiene), 19th to 23rd July, Vechta, Germany, 561-564

Wieler LH, Ilieff A, Herbst W, Bauer C, Vieler E, Bauerfeind R, Failing K, Klös H, Wengert D, Baljer G, Zahner H (2001) Prevalence of enteropathogens in suckling and weaned piglets with diarrhoea in southern Germany. J Vet Med B Infect Dis Vet Public Health 48(2):151-159

Zonderland JJ, Wolthuis-Fillerup, van Reenen CG, Bracke MBM, Kemp B, den Hartog LA, Spoolder HAM (2008) Prevention and treatment of tail biting in weaned piglets. Appl Anim Behav Sci 110:269-281 